\title{
On the Role of the Piano Artistic Direction in Vocal Teaching
}

\author{
Nan Yang and Mingyao Lu \\ College of Music ,Jiangxi University of Technology
}

Keywords: Piano artistic direction; Vocal teaching; Role

\begin{abstract}
This paper elaborates the relationship between the piano artistic direction and vocal teaching, and focus on the analysis and discussion of the role that the piano vocal art direction plays in different genres, as well as on the trial exploration the role on the piano vocal psychology that piano artistic direction takes. Through in-depth study of the piano artistic direction of vocal music teaching in all aspects, this paper points out the important role that piano artistic direction plays on the piano disciplines construction in the development process of Chinese music education. In all aspects of piano art direction embodied in vocal music teaching, including opera singing accompaniment, artistic songs singing accompaniment, vocal performances psychological teaching and other aspects, the piano artistic direction in its own way, with different skills, makes the singer perform a wide range of guidance and emotional support, so that the levels of vocal teaching reached a new height.
\end{abstract}

\section{Introduction}

In the field of music theory research, the application of vocal guidance in piano teaching has reached a new situation. More and more vocal singer and piano artist recognize the role that piano on vocal teaching plays, and more and more people put themselves into the piano to the piano artistic direction, this is believed to be "supporting role "career has also caught more and more attention and investment. However, in practice, due to various reasons on teachers' conditions, limitations on theoretical studies, artistic direction, as a very important part of piano vocal teaching, its role is still not widely recognized by the people.

In vocal teaching, most students always think that the piano lesson is simple artistic direction co-accompaniment, but completely ignored the role that piano artistic direction plays in the related links of vocal teaching. Of course, from another point of view, this is caused by the slow development and our imperfect artistic direction discipline construction. Then it is generated on this background. This paper makes an in-depth study of the piano accompaniment in vocal teaching artistic direction, meanwhile it puts forward the necessity and urgency of artistic disciplines to guide the establishment and development of Chinese music institutions, and finally describes the piano accompaniment as a discipline in vocal teaching course discipline construction.

The piano artistic direction is a comprehensive discipline, which spans both theoretical knowledge of vocal and the piano curricula. In the respective research fields of these two disciplines, we have achieved numerous research results. In connection with the aspects of both disciplines, there also have a lot of achievements. In the study experience of our predecessor, we can learn many nutrients, which provides a lot of valuable document accumulation and theoretical experience on the development and construction of this comprehensive discipline. 


\section{Relationship between the piano artistic direction and vocal teaching}

With the continuous development of the times, in order to make vocal singing and the piano accompaniment in make a better combination, the writing requirements of composer on vocal works with piano accompaniment are also increasing. They make bold innovations from different angles. They not only adds a lot of rich content for vocal music but also pay much attention on the piano accompaniment writing. The first is the change in texture of harmony, melody lines and the using of different rhythmic patterns in order to support vocal singing in a better way. In the piano accompaniment prelude, intermezzo and ending section, they add separate fragments, so the piano accompaniment has been set off vocal singing and given performance opportunities. Although the piano accompaniment and vocal performer appeared on the stage at the same time, people regard vocal sing as lead vocal and piano accompaniment a supporting role, is commonly known as "red flowers with green leaves." Such a position, is originated from how the composer understand the piano accompaniment music.

The composers guide the singer with the piano through the dialogue between vocal singing, the piano accompaniment and roles swapping so as to change the status that the piano accompaniment plays between the their cooperation, and then establish the status of the piano accompaniment. At the same time, the composer use new colors in the prelude, interlude, ending part of the song, and take efforts in connection with the coordination of piano and vocal music, so that the overall singing effect has a very good promotion, and also bring vocal singers and the piano accompanist the feeling of pleasure in the show.

During this period, the composer bring the piano accompaniment to new developing heights, and they further excavate the various functions of piano accompaniment and change people's ideas and the old inflexible piano accompaniment music pattern. They make vocal singing and piano accompaniment integrate and cooperate more perfect, and reflect a complete musical artistic image; they had also established the relationship between art equal status of both sides, so that greatly enhanced the status of the piano accompaniment. The piano accompaniment can finally show their talent on the stage, but also bring some improvement of the social status. But for many years the idea has always been to make some piano accompaniment put itself in a secondary position, and still follow the vocal singer. Therefore, they will always be a piano accompaniment instead of piano artistic guider.

The piano artistic instructor at the music colleges faces students of different grades and different levels before students enter into the school. These students are still in the stage of learning and exploration both in vocal singing skills, vocal works on the relevant knowledge of music theory and vocal language. The piano artistic instructor for students not only to set up a separate class art direction, but also to provide classroom to teach vocal accompaniment, various types of student concert and accompaniment on vocal examinations. The more important teaching task is that by a few years, they should combine music teaching and help students familiar with different languages, different styles, different types of vocal works, and help them expand their horizons and develop good artistic abilities.

There are difficult and easy ones in the piano accompaniment spectrum of vocal works. To play it well, it is not an easy task. In vocal works in normal colleges, for some easier piano accompaniment spectrum, teachers will be able to play well by visual play, but there appears more or less difficult segment in a lot of piano accompaniment spectrums. Therefore, scale, broken chords, octaves, seventh chord, legato, skipping and other playing method, etc., a good pedal control ability, the 
ability to grasp the overall playing, as well as vocal works of different styles, different emotions, different levels of certainty, we should master all of these abilities.

In the vocal accompaniment playing, mastering solid basic skills is to interpret vocal works in a better way. At the same time, we are playing good positive spectrum accompaniment, but also should pay attention to the use of improvised accompaniment. Normally we would understand improvised accompaniment is a simple accompaniment, monotonous figure and harmony texture, in fact, it is also one of basic form that reflects the artistic instructors' solid piano playing, and it has a strong practical conclusion. In a word, as a competent and excellent piano art instructor, they should fully understand the characteristics of occupation, and should also be in constant teaching practice, so that their overall quality receives a comprehensive improvement. Thus, piano art instructor should constantly improve their own teaching piano playing level, grasp extensive knowledge of music theory, so that to make their own artistic accomplishments improved. To work with full enthusiasm to throw themselves in the first line of teaching, to maintain rigorous scholarship attitude, so that they will make considerable progress in order to achieve the best artistic realm.

In the teaching of vocal music and piano teaching artistic direction, students need to learn a lot of different genres of vocal works. For example: Chinese and foreign art songs, operas excerpts and so on. There are many differences between the singing of art songs and opera excerpts, but there are many different characteristics among the piano accompaniment parts of a song. For example, the piano accompaniment is often not inferior art songs solo part and piano accompaniment opera excerpts need to imitate an orchestra of voices and require more prominent.

Thus, piano art guide teachers should give the right medicine in teaching, and make a targeted analysis of different genres characteristic vocal works with piano accompaniment, so that students in piano lessons in art direction will fully understand the relationship between sound and the accompaniment of singing, and various works in different treatment methods. In the course of the opera in concert, the string player in a band is essential. The piano art instructor in the classroom teaching should guide students to listen to music piano part. Then what is the sound of stringed instruments should imitate? Because different instruments have their own characteristics, and the sound also express different emotions. If somebody can imitate piano successfully, they can create a realistic sound effect, so that students can feel the story development of opera in concert.

In the following part, they will illustrate in two ways, interval chords imitation and tremolo imitating texture: in the opera fragment of students' learning, there are many fragments of the piano accompaniment that they are in imitation of wind instruments, in general, when composer creates the opera, they will choose woodwind, such as clarinet, oboe, flute, bassoon and other instruments, as they are often rendered melodic part. But they will rarely use of brass instruments, brass instruments because the volume is large and it appears to be easily overshadowed by the solo part. Thus, in some piano accompaniment parts, woodwinds imitation is more widely seen.

In technical aspects, it is the same to imitate stringed instrument essentials, but note that if the piano plays the part when ventilation of woodwind, the effect will be better. In teaching opera excerpts, teachers and students can clearly understand that there are many rubato processing in the songs. This process generally has two aspects, one is the work itself or the requirements of singing traditional treatment; the second is that a teacher summed up the play and interpret of a melody or a whole music in the teaching process. As every vocal teacher understands the different songs in a different way, so they teach students the way to master the method of processing rubato respective 
also in a different way. But on the whole in line with the development of music and opera singing traditional methods.

During the teaching process that the piano artistic instructor guide the students, teachers must firstly they should respect the rubato manipulation that embodied when vocal artistic instructor teach students to sing, and they teach through their deep understanding of opera and the the texture of piano part, therefore they guide students to correctly treat the handle the rubato within the capabilities. Rather than blindly imitating others, they believe that they should follow the singer where to handle the rubato. As the ability of students is limited, therefore, the rubato manipulation will use the breath, breathing, and many other vocal skills, so it is a difficult skill to master.

As for the piano artistic director, you need to understand where to use rubato in an opera music, and where they should be play in strict accordance with the requirements of speed and rhythm. In the recitative and aria of an opera, the rubato manipulation is also different. In opera recitatives, the composer usually focus and effect they want to express very clearly written in their notation, while the singer will not have to do too much handling and processing but it is possible to achieve the effect of the concert; and in opera arias, the emergence of rubato manipulation is more frequently, such as: the singer use coloratura, weak sound singing in the paragraphs to show skills, will appear rubato manipulation; in the treble part of a sound part, it appears at the end of the aria or climax, and it is usually require to extend; in many concert works, there are many conventional handling methods, there will also appear rubato manipulation.

In the beginning of a work, the piano accompaniment speed is very important to guarantee the flow of play and make their music mood excited. It is noted that in the later half beat of the first beat among each measure, composers will use dotted notes, which will vividly the characters' inner excitement. When they play here, they want to grasp the vocal intensity distribution, and the crescendo and decrescendo can make more clear but to pay attention to the sense of proportion. The fourth section of the piano part, there appeared the case that three voices go at the same time. Now the rhythm in the medium part will not only be not reduced, but need for greater efforts to make the voices stronger to support the vivid image of the music. Starting from the 14th Section, the song entered the second paragraph of the single trilogy, and from this paragraph the song change from c minor to E major, then the music mood has changed over from the beginning excitement to the quiet and affectionate mood.

For the right-hand triplets of the piano part, they should not only play with singing quality, but also control the volume. At the end of the second part, that is the 25th bar, they should play the piano with a crescendo and express the feeling of a better life. In the following 26th section, the song appeared a transpose, right hand single tone follow the singer's theme, while the left-hand accompaniment rolling and always maintained the rhythm pattern in the beginning, and then back to excited emotion in the first paragraph.

It is worth mentioning that, in the end of the four sections, where the right hand part appeared the rhythm in Schubert's song "Ave Maria", and Schumann use the melody here, perhaps is in worship and his wife Clara praise, perhaps is to commemorate and respect Schubert's predecessors, in short, Schumann use the melody here, brought the finishing touch to end the "Dedication". Therefore, when they play the last two phrases, they should play meaningfully, and the second sentence should be more sweet and lyrical than the first one, and finally end the whole song and draw a successful conclusion. 
Throughout the role that the piano plays in vocal artistic direction in different genres, whether it is the particularity of opera accompaniment or just the skills of art song accompaniment, it has a strong assistant of the vocal teaching. In the actual teaching opera and art songs, the vocal music teacher and piano artistic instructors must follow the basic requirements and style of the opera and art songs, and depend on different part and teach targetedly, and finally find ways and means of different genres of vocal works in their teaching. Through in-depth study of the piano part, so that all aspects of vocal music teaching series will interact and absorb each other, so that the two disciplines integrate together better and bring better teaching results.

The vocal performance is a comprehensive art, where artist not only need auditory presentation, but also through visual imagery to express the emotion of the song. In other words, when the audience heard the song, they also want to see the singer's performances. Lyricist, composer presents a complete song in front of the singer, while singers face rigid notes and lyrics, then how to interpret the content of the song want to express in a better way? This requires in-depth study on songs so as to make rigid notes and lyrics become living music. Therefore, the singer is not only charged with the task to express the intention of songwriters, but also ongoing creation should be conducted on the basis of the song itself, so that the song is more full of vitality.

The vocal music performance and piano artistic direction are interdependent and mutually assist another, therefore, while the singer performed at the second creation, the piano artistic director should also assist to achieve a better upgrade in performing. The performing arts of singing is a process of complex psychological activities, which needs singers to have a comprehensive ability, such as: music sensation and perception, emotes, music movement, music, imagination, musical memory, etc., these capabilities are to test the ability of the artist. As a piano artistic director, they should not only guide and remind on the basic quality of the singer, and the singer needs to make a deeper discussion and research on the content of the vocal works, therefore, they can achieve perfection in stage performances.

When vocal learners are at their stage practice, no matter singer or piano accompaniment, they should pay sufficient attention to preparation. The singer should strengthen their proficiency on lyrics, while players want to practice difficult fragments and make a consideration and research on recurrent problems of their cooperation so as to seek unnecessary mistakes in the show. In collaboration with piano accompaniment, and they have a certain understanding before the show through a lot of exercises and cooperation, and therefore before the show the two sides should give enough confidence to each other, especially the piano artistic director must maintain a strong effort, while in the play, they must throw himself into the music. For some inexperienced or student singers, the piano artistic director must psychologically acknowledged the frequent errors during the cooperation process, and the singer will be prone to mistakes in stressful situations. If mistakes appear, the piano artistic director should make a good resolution in order not to affect the actual performance.

\section{Conclusions}

The piano artistic direction is an important and indispensable part in vocal music teaching, and it has a very important role in vocal music teaching, whose purpose is to enable students to extend the teaching achievement of vocal music core subjects through piano accompaniment lessons for some vocal music learning students. Therefore, both should go hand in hand without bias. As piano artistic director, they should not only have a high piano playing skills and a wealth of stage 
experience, but also master the theoretical knowledge of vocal music teaching and singing, as well as be familiar with a lot of vocal works to help students on the proper use of singing and vocal technique ways to make students achieve improvements in terms of pitch, rhythm, articulation, phrase inlet and musical expression by piano accompaniment lesson.

In vocal music teaching, the piano artistic direction plays its role within its power, so that the vocal singer may have a better understanding of the song and interpret it, and this guidance form will gradually be recognized and valued. The piano artistic director can not always stay in the piano accompaniment level after its continuous practice learning, but also have a full range of knowledge on vocal disciplines, as mentioned in Part IV, the role that the piano artistic direction played on vocal music performance psychology, have made an analysis and research of the intersection of two disciplines, and this is one of the innovations of this paper.

The vocal performance and piano artistic direction on the stage is an integral whole, and the two disciplines are all professional performers and can not separate from singing and playing as well as the stage. The piano artistic direction firstly need excellent professional knowledge, and secondly to solve psychological problems and simultaneously solve their own problems that occur at any time in the singing. Thus, piano artistic director and vocal music singer, must make full preparations before stepping into the stage, which preparation includes the technical preparation, and more importantly, the psychological preparation.

Therefore, the piano artistic direction plays significant psychological role in vocal performance psychology, especially in the arena, it not only acts as a "green leaf" role, and the normal level of playing levels under piano artistic guidance and rich stage presence also greatly limit and determine the playing level of vocal singer. In summary, the piano artistic direction plays an important role not only in vocal music teaching, but also an integral part of psychology in the vocal performance. Therefore, they need to assist vocal music teaching and vocal performances by piano artistic direction so that the two parties on stage can reach a unified musical expression and complement of mental activity, Besides, they need a higher level to improve and hone so that vocal performance and piano artistic direction the two disciplines can combine in a better way.

\section{References}

[1] Joseph Gath. The Pianism [M] Beijing: People's Music Publishing Press, 1983.

[2] Zhao Xiaosheng. The Way to Play the Piano [M]. Changsha: Hunan Education Press, 1991.

[3] Zou Changhai. The Vocal Music Psychology [M] Beijing: People's Music Publishing Press, 2000.

[4] Zhang Jialin. The Piano Accompaniment and Its Techniques [M] Beijing: Central Music Conservatory Press, 2004.

[5] Yang Mannian. The Research on Vocal Training [M] Gansu: Gansu People's Publishing Press, 2006.

[6] Yu Dugang. The Vocal Art Aesthetics [M] Beijing: People's Music Publishing Press, 2005.

[7] Shijun Liang. The Vocal Art of Recordings [M] Beijing: People's Music Publishing Press, 2004.

[8] Guan Jinyi. Western Vocal Art History [M] Beijing: People's Music Publishing Press, 2005

[9] Shi Weizheng. The Vocal Basis [M] Beijing: People's Music Publishing Press, 2002. 
[10] Li Xiaoer. National Vocal Music Art [M]. Hunan Art Publishing Press, 2001.

[11] Xu Xiaogu. Musical Performance and Education [M] Beijing: People's Music Publishing Press, 1986.

[12] Yu Yishou. The Anthology of Vocal Performing Arts [M] Beijing: People's Music Publishing Press, 1980

[14] Pan Naixian. The Vocal Practical Guide [M] Beijing: People's Music Publishing Press, 1994 